\title{
O Termo Planta-Daninha
}

\author{
Robinson Antonio Pitelli
}

Desde o início da agricultura e da pecuária, as plantas que infestavam espontaneamente as áreas de ocupação humana e não eram utilizadas como alimentos, fibras ou forragem eram consideradas indesejáveis. Essas plantas, em termos de nomenclatura botânica, são consideradas pioneiras, ou seja, plantas evolutivamente adaptadas para a ocupação de áreas onde, por algum motivo, a vegetação original foi profundamente alterada, ocorrendo grande disponibilidade de habitats ao crescimento vegetal. Elas têm a função de criar habitats adequados ao início de uma sucessão de populações, que culmina no restabelecimento da vegetação original.

Com o desenvolvimento da sociedade humana, as áreas agrícolas foram sendo expandidas e houve grande continuidade entre elas, o que permitiu a expansão geográfica, a paulatina evolução das plantas pioneiras para áreas de atividade antrópica e o aparecimento de novas espécies. Assim, as comunidades infestantes foram se tornando cada vez mais densas, diversificadas e especializadas na ocupação dos agroecossistemas, passando a interferir profundamente nas atividades agrícolas, recebendo o conceito de planta daninha. Outros tipos de planta também prejudicavam a produção agropecuária, como as plantas parasitas.

A expressão planta daninha não se refere a qualquer função biológica conhecida. As plantas que atualmente causam danos às atividades humanas, à saúde do homem e ao meio ambiente, quando ocorrendo fora de sua área de distribuição geográfica ou em tamanhos populacionais acima da capacidadesuporte do ambiente, têm várias designações compativeis com sua função biológica, como: planta parasita, planta exótica invasora, planta pioneira, planta trepadeira, entre outras.

No entanto, todas essas plantas têm um caráter comum: sua indesejabilidade no local, época e forma em que ocorrem. Elas são indesejadas em virtude dos problemas que causam à produção agrícola, aos custos de produção, à manutenção da integridade de reservas ambientais, ao aumento dos riscos com acidentes em rodovias, ferrovias e hidrovias, à integridade de ambientes aquáticos e à geração de energia elétrica, entre outras importantes interferências.

Há necessidade de um termo que englobe todas as plantas que estão na categoria de indesejadas, independentemente de sua função biológica. O Dr. Paulo Nogueira de Camargo (ESALQ/USP) propôs o termo mato, argumentando sobre a etimologia da palavra. No entanto, o termo mato pressupõe um coletivo de plantas e não um indivíduo ou uma população. Mato poderia ser uma palavra mais adequada para designar a comunidade de plantas que coloniza determinado local, sem qualquer ligação com sua indesejabilidade. Esse autor propôs ainda o termo mato-espécie para se referir a uma unidade taxonômica.

Nessa mesma época, o Dr. Giorgio De Marinis (UNESP, Rio Claro) propôs o termo malerba para designar as plantas que causam danos a alguma atividade do homem ou ao ambiente. O termo tem origem latina e é uma adaptação de termos adotados pelas línguas castelhana (mala hierba ou maleza), francesa (mauvaise herb) ou italiana (mallerbe).

Os termos planta invasora, planta infestante e planta adventícia são bastante utilizados, mas apenas dão ideia do deslocamento da planta de sua área original de distribuição geográfica, sem se relacionar com a indesejabilidade. Nem sempre uma planta deslocada de sua área original promove alterações suficientes para caracterizar a indesejabilidade. Ademais, com frequência, uma população vegetal que causa danos a determinada atividade humana ou cultura agrícola não está deslocada de sua área original, e os problemas são fruto das alterações ambientais promovidas pelo homem, que permitiu que a população ultrapassasse a capacidade-suporte do ambiente e, por isso, passou a promover danos ao ambiente ou às atividades humanas. Um exemplo bastante claro desse comentário ocorre com a macrófita aquática Egeria densa, nativa das bacias dos rios Aporé, Paranaíba e Paraná. A introdução do tucunaré (Cichla spp.) e de outros peixes carnívoros vorazes causou expressiva redução da fauna herbívora que mantinha o controle das populações vegetais no corpo dos rios e nos reservatórios. A condição lêntica da água nos reservatórios e a ausência de herbivoria permitiram que essa macrófita aumentasse drasticamente seu tamanho populacional e causasse problemas à qualidade da água, à atividade pesqueira, aos esportes náuticos e à geração de energia elétrica.

Planta Daninha, Viçosa-MG, v. 33, n. 3, 2015 
A expressão planta daninha, embora não designe qualquer função biológica conhecida, no Brasil tem significado social e econômico conhecido. O termo tem seu componente antropocêntrico, o que também ocorre no vernáculo dos diversos povos. Outros povos estabeleceram terminologia própria para esse tipo de vegetação, como "weed", na língua inglesa, e "unkraut", no alemão.

A proposta deste texto é pela utilização da palavra planta daninha com a ligação de um hífen, planta-daninha, para designar as plantas que ocorrem em locais ou situações onde são indesejadas. As justificativas para essa proposta são:

A palavra composta não tem o compromisso de significação da combinação das palavras isoladas e pode ser considerada um neologismo;

Em todo e qualquer sistema de comunicação há três elementos: o codificador, o decodificador e a mensagem. O codificador é aquele que emite a mensagem e o decodificador é aquele que a recebe. Para entendê la, é importante que o código utilizado na transmissão da mensagem seja conhecido pelos dois. A mensagem será melhor entendida quanto maior for a intimidade que ambos tiverem com o código utilizado. O termo planta daninha é utilizado há muito tempo no Brasil, pode ser considerado como consagrado pelo uso popular e há perfeito entendimento de sua significação. Não são poucos os exemplos de termos que transmitem uma ideia entre codificador e decodificador diferente do significado das palavras que os compõem, como pasta de dente, guarda-sol e outros.

Cada palavra tem sua denotação e sua conotação. A denotação é o significado primeiro da palavra, e a conotação é o sentido que uma palavra adquire em um determinado contexto, a qual pode ser um ritual, uma mensagem publicitária ou uma atividade profissional. Assim, a mensagem será melhor entendida quanto maior intimidade os comunicantes tiverem com o código utilizado e, portanto, quanto mais integrada a palavra estiver ao conjunto de termos que são normalmente utilizados por ambos. Desse modo, a emissão da palavra escolhida como código, embora de grande significado para o codificador e o decodificador, pode provocar surpresas às pessoas estranhas ao processo específico da comunicação, o que poderia acontecer se a palavra estivesse fora do conjunto de termos comuns a eles.

Por isso, a recomendação deste artigo é pela utilização do termo planta-daninha para designar plantas que ocorrem em situação em que não são desejadas pelo entendimento do homem, em razão de interferências em atividades humanas, na qualidade de vida e na proteção ambiental.

É importante salientar que a vegetação que infesta áreas agrícolas e pecuárias poderá ser designada por terminologia utilizada em ecologia. Para entendimento dessa terminologia, é interessante antecipar algumas definições.

População refere-se ao conjunto de indivíduos da mesma espécie que habitam determinada área. Nesse caso, refere-se a uma determinada planta-daninha, como Bidens pilosa e Ageratum conyzoides. Ao conjunto de todas as populações de plantas-daninhas que infestam as áreas agrícolas, pastagens, pomares e reflorestamentos atribui-se o nome de comunidade infestante. No entanto, este termo referese apenas às plantas daninhas e não inclui a planta de interesse econômico cultivada na área, e não há dúvida de que as interações entre elas são múltiplas e importantes.

Cenoses são conjuntos de populações grupadas por um critério, que pode ser taxonômico, funcional ou outro qualquer. As plantas daninhas que ocorrem em agroecossistemas poderiam ser chamadas de agrofitocenoses, pois se trata de plantas que habitam ecossistemas agricolas, silviculturais ou pastoris. Nesse contexto, as plantas cultivadas passam a fazer parte do conjunto. No entanto, o termo é restritivo e não contempla plantas que ocorrem em áreas urbanas, ambientes aquáticos e outros. Assim, a recomendação deste texto é pelo uso do termo comunidade infestante para designar o conjunto de plantasdaninhas que habita determinado ambiente, incluindo o local de infestação quando é necessário ser mais específico, como comunidade infestante de lavouras de café, comunidade infestante de margens de rodovias ou comunidade infestante de linhas de transmissão elétrica.

Concluindo, o termo planta-daninha deve ser adotado para designar qualquer planta superior que interfira nos interesses do homem e no meio ambiente, e o termo comunidade infestante seguido da qualificação do ambiente de ocorrência deve ser adotado nas publicações em português derivadas de autores brasileiros.

Planta Daninha, Viçosa-MG, v. 33, n. 3, 2015 